\title{
Contrasting effects of heat shock during in vitro maturation on development of in vitro-fertilized and parthenogenetic bovine embryos
}

\author{
Luiz Sergio Almeida Camargo ${ }^{1}$ (D) | Fernanda Queiros Costa ${ }^{2}$ | Michele Munk ${ }^{3}$ | \\ Sabine Wohlres-Viana ${ }^{3}$ | Raquel Varela Serapião ${ }^{4}$ | Bruno Campos Carvalho ${ }^{1}$ | \\ Paulo Henrique Campos Jr $r^{5}$ | Alex Cabral Vieira ${ }^{6}$ | Luiz Altamiro Garcia Nogueira ${ }^{7}$ | \\ Joao Henrique Moreira Viana ${ }^{1}$
}

\author{
${ }^{1}$ Brazilian Agricultural Research Corporation \\ (Embrapa), Dairy Cattle, Juiz de Fora, Brazil \\ ${ }^{2}$ UENF, Campos dos Goytacazes, Brazil \\ ${ }^{3}$ UFJF, Juiz de Fora, Brazil \\ ${ }^{4}$ PESAGRO, Valença, Brazil \\ ${ }^{5}$ UFSJ, Sao Joao Del Rei, Brazil \\ ${ }^{6}$ UFV, Viçosa, Brazil \\ ${ }^{7}$ UFF, Niterói, Brazil \\ Correspondence \\ Luiz Sergio Almeida Camargo, Embrapa, Rua \\ Eugenio do Nascimento, 610, Dom Bosco, \\ Juiz de Fora, MG, 36038-330, Brazil. \\ Email: luiz.camargo@embrapa.br \\ Funding information \\ Conselho Nacional de Desenvolvimento \\ Científico e Tecnológico; Fundação de \\ Amparo à Pesquisa do Estado de Minas \\ Gerais, Grant/Award Number: APQ 543-14 \\ and CVZ-PPM 107-17
}

\begin{abstract}
This study investigated the influence of heat shock during in vitro maturation on embryo development following in vitro fertilization (IVF) or parthenogenesis (Part). Immature bovine cumulus-oocyte complexes were exposed to heat shock $\left(41.0^{\circ} \mathrm{C}\right)$ during the first $12 \mathrm{hr}$ of in vitro maturation (IVM), followed by $12 \mathrm{hr}$ at $38.5^{\circ} \mathrm{C}$. Control group consisted of in vitro maturation for $24 \mathrm{hr}$ at $38.5^{\circ} \mathrm{C}$. Oocytes were in vitrofertilized or activated with ionomycin and cultured in vitro for $192 \mathrm{hr}$ post-in vitro insemination or parthenogenetic activation (hpia). There was an interaction $(p<.01)$ between temperature of IVM and method of oocyte activation (IVF or Part) for cleavage at 48 hpia. Heat shock had a negative impact $(p<.01)$ on cleavage of IVF embryos, whereas no ( $p>$.05) effect was found in the Part embryos. Embryo development towards blastocyst stage at 168 and 192 hpia decreased in both IVF and Part embryos derived from heat-shocked oocytes. Heat shock increased $(p<.05)$ the apoptotic index in Part blastocysts, but no effect $(p>.05)$ was found in IVF counterparts. Heat shock also down-regulated the expression of AQP3 $(p<.01)$ and up-regulated the expression of HSP70.1 $(p<.01)$ in Part blastocysts, whereas it down-regulated the expression of ATP1A1 $(p<.05)$ in IVF blastocysts. In conclusion, the effects of heat shock during IVM on early embryo cleavage and blastocyst apoptosis are influenced by the method of oocyte activation and expression of some genes can be disturbed in embryos derived from heat-shocked oocytes.
\end{abstract}

\section{1 | INTRODUCTION}

Cows under heat stress display several physiological alterations that can affect reproduction (Hansen et al., 2001). In such conditions, rectal temperature may exceed $41^{\circ} \mathrm{C}$ (Ealy, Drost, \& Hansen, 1993) and impact on early embryo development (Putney, Drost, \& Thatcher, 1988). Studies have shown that development of bovine oocytes is impaired when they are cultured in vitro under $41^{\circ} \mathrm{C}$ for a short time
(Edwards, Bogart, Rispoli, Saxton, \& Schrick, 2009; Roth \& Hansen, 2005). Indeed, the induction of heat shock (elevated temperature for $12 \mathrm{hr}$ ) can disturb oocyte maturation and further fertilization, resulting in zygotes with low developmental competence (Edwards \& Hansen, 1997; Roth \& Hansen, 2005). During in vitro maturation, the heat shock increases the proportion of apoptotic oocytes (Roth $\&$ Hansen, 2004a, 2005) but not the proportion of apoptotic cells in blastocysts. 
The abundance of some transcripts important for maturation and embryo development, such as C-MOS, GDF9 and POUF5F1, can be altered when oocytes at germinal vesicle stage are exposed to heat shock (Gendelman \& Roth, 2012a). Early in vitro-fertilized embryos and blastocyst derived from oocytes collected at the warm season also displayed altered expression of POUF5F1 (Gendelman, Aroyo, Yavin, \& Roth, 2010; Gendelman \& Roth, 2012b). The effect of heat shock on the amount of mRNA stored in the maternal cytoplasm, as found in bovine oocytes exposed to heat shock either in vivo or in vitro (Gendelman \& Roth, 2012a, 2012b), suggests that heat shock degrades mRNA stored in the oocyte cytoplasm, which may be one of the causes for reduced oocyte competence. Nonetheless the importance of maternal factors on development post-fertilization, paternal (sperm) factors can also contribute to the early embryo development.

Some sperm factors, such as PLC zeta 1 and post-acrosomal WW-domain binding protein, are considered to play an important role in oocyte activation (Amdani, Yeste, Jones, \& Coward, 2015; Ross et al., 2008; Yeste, Jones, Amdani, \& Coward, 2017). Sperm can also deliver microRNAs or mRNAs to the fertilized oocyte and influence further embryo development (Boerke, Dieleman, \& Gadella, 2007; Hamatani, 2012). Sperm chromatin may be important for transcriptional activity of the pre-implantation embryo, influencing the synthesis of new RNAs (Bui et al., 2011). However, it is not known whether heat-shocked oocytes present a distinct requirement for activation and/or of sperm factors, which could influence the early cleavages and further development. One approach to find out potential differences is to compare the development of heat shock oocytes after fertilization and after chemical activation (parthenogenesis). Parthenote embryos are generated without participation of spermatozoa and thus lack sperm factors. In addition, some differences in mechanism of activation between fertilization and parthenogenesis exist (Tang, Dong, Huang, \& Sun, 2000) and may influence the development of a heat-shocked oocyte. Thus, in this study we aimed to evaluate the development of both in vitro-fertilized and parthenogenetic embryos derived from oocytes matured in vitro under control $\left(38.5^{\circ} \mathrm{C}\right)$ or heat shock $\left(41^{\circ} \mathrm{C}\right)$ temperature.

\section{2 | MATERIALS AND METHODS}

All chemicals were from Sigma Chemical unless stated otherwise. All experimental procedures followed ethical guidelines for animal experimentation and were approved by local committee (CEUA EGL $02 / 2015$ protocol).

\section{1 | Experimental design}

Immature bovine cumulus-oocyte complexes (COCs; $n=1,886$ ) were randomly allocated into a $2 \times 2$ factorial design: temperature of in vitro maturation (control or heat shock temperatures) and method of activation (in vitro fertilization or parthenogenesis). The control temperature was $38.5^{\circ} \mathrm{C}$ for $24 \mathrm{hr}$, and heat shock temperature was $41^{\circ} \mathrm{C}$ for $12 \mathrm{hr}$ plus $38.5^{\circ} \mathrm{C}$ for additional $12 \mathrm{hr}$. Cumulusoocyte complexes matured under either temperature conditions were in vitro-fertilized or parthenogenetically activated (IVF and Part groups, respectively). Cleavage rate was evaluated at $48 \mathrm{hr}$ post-in vitro insemination or activation (hpia) and blastocyst rates at $168 \mathrm{hr}$ and $192 \mathrm{hpia}$, respectively. A total of 11 replicates were carried out. The blastocysts were fixed for total cell number and apoptotic cell counting. Relative abundance of transcripts of peroxiredoxin1 (PRDX1), ATPase, $\mathrm{Na}+/ \mathrm{K}+$ transporting, alpha 1 polypeptide (ATP1A1), aquaporin 3 (AQP3) and heat shock $70 \mathrm{kDa}$ protein 1A (HSP70.1) genes was compared between control and heat shock groups in IVF or Part blastocysts.

\subsection{Collection, heat shock and in vitro maturation of oocytes}

Ovaries of predominantly Bos indicus crossbred cows were obtained from a local commercial slaughterhouse (Fripai) and transported to the laboratory in saline solution $(0.9 \% \mathrm{NaCl}$ with $0.1 \mathrm{~g} / \mathrm{L}$ streptomycin) at $34-36^{\circ} \mathrm{C}$. Follicles with $2-8 \mathrm{~mm}$ diameter were aspirated, and COCs with more than three compact layers of cumulus cells and oocyte with homogeneous cytoplasm were randomly allocated into the groups, according to the experimental design. In vitro maturation was performed in tissue culture medium (TCM-199; Gibco Life Technologies, Inc.) supplemented with $20 \mu \mathrm{g} / \mathrm{ml}$ follicle-stimulating hormone (FSH; Pluset, Calier), $0.36 \mathrm{mM}$ sodium pyruvate, $10 \mathrm{mM}$ sodium bicarbonate and $50 \mathrm{mg} / \mathrm{ml}$ streptomycin/penicillin in a humidified atmosphere of $5 \% \mathrm{CO}_{2}$ in air and $100 \%$ humidity.

\section{3 | Fertilization, parthenogenesis and in vitro culture}

A pool of frozen/thawed motile spermatozoa from three Holstein bulls was obtained after one centrifugation at $9,000 \mathrm{~g}$ for $5 \mathrm{~min}$ in Percoll discontinuous density gradient (45\%-90\%). The pellet was centrifuged again at $9,000 \mathrm{~g}$ for $3 \mathrm{~min}$ in Fert-TALP medium. In vitro fertilization was performed using $2 \times 10^{6}$ spermatozoa/ml for $21 \mathrm{hr}$ in $100-\mu \mathrm{l}$ drops of Fert-TALP supplemented with $20 \mu \mathrm{g} / \mathrm{ml}$ of heparin and $6 \mathrm{mg} / \mathrm{ml}$ of fatty acid-free BSA fraction $\mathrm{V}$, covered with mineral oil, in a humidified atmosphere of $5 \% \mathrm{CO}_{2}$ and $38.5^{\circ} \mathrm{C}$ in air. After in vitro fertilization, the presumptive zygotes were denuded by vortex in $0.1 \%$ hyaluronidase solution. Some oocytes were fixed after IVF for pronucleus formation analysis.

Parthenogenesis was induced by ionomycin and 6-DMAP. After in vitro maturation (IVM), COCs were denuded by vortex in $0.1 \%$ hyaluronidase solution and activated by exposure to $4.8 \mu \mathrm{M}$ ionomycin for 5 min followed by 4 hr in 2 mM 6-DMAP. After IVF or Part, the presumptive zygotes were cultured in a modified CR2aa medium with $2.5 \%$ of foetal calf serum (Nutricell Nutrientes Celulares) under $5 \% \mathrm{CO}_{2}, 5 \% \mathrm{O}_{2}$ and $90 \% \mathrm{~N}_{2}$ at $38.5^{\circ} \mathrm{C}$. 


\subsection{Analysis of pronuclei formation in IVF oocytes}

In vitro-fertilized oocytes were examined for pronucleus formation at $21 \mathrm{hr}$ after fertilization. Oocytes were denuded by vortexing in $0.1 \%$ hyaluronidase solution for $5 \mathrm{~min}$ and then fixed overnight in a methanol:acetic acid solution (3:1). Afterwards, oocytes were stained with aceto-orcein ( $2 \%$ orcein in $45 \%$ acetic acid) and analysed under phase-contrast microscopy at $\times 1000$ magnification. Pronuclear status was determined by the presence of a single, two or more pronuclei per oocyte.

\section{5 | Apoptosis analysis}

Blastocysts at 192 hpia were submitted to terminal deoxyribonucleotidyltransferase-mediated dUTP-digoxigenin nick end-labelling (TUNEL) staining using a commercially available kit (DeadEnd Fluorimetric TUNEL System, Promega) according to the manufacturer's instructions. Briefly, embryos ( $n=97$ ) were fixed in $4 \%$ paraformaldehyde at $4^{\circ} \mathrm{C}$ and then permeabilized with $0.2 \%$ Triton $\mathrm{X}-100$ (Promega), both in PBS (Nutricell). Positive control embryos were previously treated with DNase (Promega). After permeabilization, positive control and target samples were incubated in $100-\mu \mathrm{L}$ drops with reagent mix containing enzyme solution (terminal deoxynucleotidetransferase enzyme) and $90 \%$ staining solution (dUTP-fluorescein conjugate) for $1 \mathrm{hr}$ at $37^{\circ} \mathrm{C}$ in a dark humid chamber. Negative control embryos were incubated only in the staining solution without enzyme solution. After that, embryos were stained with Vectashield (Vector Laboratories Inc.) plus 4'6-diamidino-2-phenylindole (DAPI) and mounted on slides for evaluation by fluorescence microscopy. Total cell number and apoptotic cell number per embryo were counted, and apoptotic cell index was calculated as the ratio of apoptotic cell/total cell number.

\section{6 | Total RNA extraction and reverse transcription in matured oocytes and blastocysts}

Blastocysts from three different replicates were frozen in liquid nitrogen before RNA extraction. Total RNA was extracted from three pools of ten blastocysts per treatment using the RNeasy Micro Kit (Qiagen $\mathrm{GmbH}$ ), according to the manufacturer's instructions, and treated with DNase I (27 units for 15 min at room temperature for every sample). The RNA samples were reversely transcribed using the SuperScript III First-Strand Synthesis Supermix (Invitrogen) according to the manufacturer's instructions, using oligo(dT) ${ }_{20}$ primers, dNTP mix, SuperScript ${ }^{\mathrm{TM}}$ III RT, RNaseOUT ${ }^{\mathrm{TM}}, \mathrm{MgCl}_{2}$, RT buffer in a final volume of $20 \mu \mathrm{l}$. The samples were first incubated at $65^{\circ} \mathrm{C}$ for $5 \mathrm{~min}$ and then at $50^{\circ} \mathrm{C}$ for $50 \mathrm{~min}$. The reaction was terminated at $85^{\circ} \mathrm{C}$ for $5 \mathrm{~min}$ and then chilled on ice. After that, RNase $\mathrm{H}$ was added to the samples and incubated at $37^{\circ} \mathrm{C}$ for $20 \mathrm{~min}$. The RNA and CDNA quantification analyses for each sample were performed using $1 \mu \mathrm{l}$ of sample in spectrophotometer nd-100 (NanoDrop).

\section{7 | Relative quantification by real-time PCR}

Relative quantification was performed in triplicate using RealTime PCR (ABI Prism 7300 Sequence Detection Systems, Applied Biosystems). Reactions were prepared using a mixture of Power SYBR $^{\circledR}$ Green PCR Master Mix (Applied Biosystems), primers, nuclease-free water and cDNA. The amount of cDNA used in the reactions ranged according to the optimal concentration previously identified. About 600 ng cDNA per reaction for PRDX1 and HSP70.1, 200 ng cDNA for beta-ACTIN (ACTB), glyceraldehyde 3-phosphate dehydrogenase (GAPDH), AQP3 and ATP1A1 genes and $400 \mathrm{ng}$ cDNA for $\mathrm{H} 2 a$ gene were used. cDNA template was denatured at $95^{\circ} \mathrm{C}$ for $10 \mathrm{~min}$, followed by $45 \mathrm{cycles}$ of $95^{\circ} \mathrm{C}$ for $15 \mathrm{~s}$, gene-specific primer annealing temperature for $30 \mathrm{~s}$ (Table 1) and elongation at $60^{\circ} \mathrm{C}$ for $30 \mathrm{~s}$. After each PCR run, a melting curve analysis was performed to confirm that a single specific product was generated. No-template controls (NTC), comprised of the PCR mix without nucleic acid, were also run with each primer to confirm the absence of contaminations. Primer efficiency was calculated using LinRegPCR software (Ramakers, Ruijter, Deprez, \& Moorman, 2003) for each reaction. The primer efficiency was 1.85, 1.84, 1.80, 1.86, 1.78, 1.81 and 1.72 for ACTB, GAPDH, H2a, PRDX1, AQP3, ATPase1 and HSP70.1

TAB LE 1 Primer sequences used for relative gene expression analysis by real-time polymerase chain reaction

\begin{tabular}{|c|c|c|c|c|}
\hline Gene symbol & Primer sequence $\left(5^{\prime}-3^{\prime}\right)$ & Annealing temperature $\left({ }^{\circ} \mathrm{C}\right)$ & Fragment size (bp) & GenBank accession number \\
\hline ATP1A1 & $\begin{array}{l}\text { F-TGCTGCTTTCСTTTCCTACTG } \\
\text { R-AGCTTCCGGACTTCGTCATA }\end{array}$ & 52 & 129 & NM_001076798 \\
\hline AQP3 & $\begin{array}{l}\text { F-ACCGATCTAGCCCCTCATCT } \\
\text { R-CCAACTCCACCGACAGAATC }\end{array}$ & 53 & 136 & NM_001079794 \\
\hline PRDX1 & $\begin{array}{l}\text { F-TGCCAGATGGTCAGTTCAAG } \\
\text { R-CCTTGTTTCTTGGGTGTGTTG }\end{array}$ & 53 & 223 & NM_174431 \\
\hline HSP70.1 & $\begin{array}{l}\text { F-AACAAGATCACCATCACCAACG } \\
\text { R-TCCTTCTCCGCCAAGGTGTTG }\end{array}$ & 59 & 275 & NM_203322 \\
\hline $\mathrm{H} 2 \mathrm{a}$ & $\begin{array}{l}\text { F-GCCATCCTGGAGTACCTCAC } \\
\text { R-TGGATGTGTGGAATGACACC }\end{array}$ & 52 & 176 & NM_174809 \\
\hline ACTB & $\begin{array}{l}\text { F-GACATCCGCAAGGACCTCTA } \\
\text { R-ACATCTGCTGGAAGGTGGAC }\end{array}$ & 53 & 205 & NM_173979 \\
\hline GAPDH & $\begin{array}{l}\text { F-CAGGAGCACGAGAGGAAGAGTT } \\
\text { R-GGCCTTAGAGATGGAAACATGTG }\end{array}$ & 52 & 102 & NM_001034034 \\
\hline
\end{tabular}


genes, respectively. Expression of ACTB, GAPDH and $\mathrm{H} 2 a$ genes was used as reference gene. Calculations of relative quantification were performed by the comparative $\mathrm{Ct}$ method. Data of control temperature $\left(38.5^{\circ} \mathrm{C}\right)$ were used as calibrators in order to calculate the relative abundance of transcripts in IVF or Part blastocysts. Values are shown as fold change relative to the calibrator.

\section{8 | Statistical analysis}

Data of cleavage, blastocyst production and apoptosis index were analysed by binary logistic regression (Proc Logistic) using the SAS statistical software (version 9.1), in order to determine the effect of temperature, method of activation and interactions on the likelihood of development. The $95 \%$ confidence interval $(\mathrm{Cl})$ was used to estimate the precision of odds ratio (OR). The null hypothesis was tested by chi-square test. Total cell number and apoptotic cell number were analysed by the linear mixed model (Proc Mixed). Proportional data of pronucleus formation after IVF were analysed by chi-square test. Relative quantification analyses were performed by REST software (Pfaffl, Horgan, \& Dempfle, 2002) and were based on primer efficiency, using a pairwise fixed reallocation randomization test using data of respective control group as calibrator (set to 1). Differences were considered significant at the 95\% confidence level $(p<.05)$. Values are illustrated as mean \pm standard error of the mean (SEM).

\section{3 | RESULTS}

\subsection{Effect of temperature during IVM on pronuclei formation after IVF}

The elevated temperature $\left(41^{\circ} \mathrm{C}\right)$ for first $12 \mathrm{hr}$ of IVM decreased $(p<.05)$ the pronuclei formation rate after in vitro fertilization $(74 \%$; $143 / 193)$ when compared to the control group (84\%; 158/187). No effect $(p>.05)$ of temperature on polyspermy rate was observed (6.9\%, 13/187; and 9.8\%, 19/193, for control and heat shock oocytes, respectively).

\section{2 | Effect of temperature during IVM and of method of oocyte activation on cleavage and blastocyst production}

Cleavage rates were evaluated at 48 and blastocyst rates at 168 and 192 hpia. There was a significant interaction $(p<.01)$ between temperature of IVM and method of oocyte activation for cleavage rate at 48 hpia. Heat shock during IVM reduced $(p<.01)$ the ability of IVF zygotes to develop until 48 hpia, with less chance to cleave for those from heat shock group when compared to the control group (OR $=0.53 ; \mathrm{Cl} 95 \%=0.3,0.7)$. In contrast, no effect of heat shock during IVM was found in the Part embryos $(p>.05)$. Cleavage rate was greater $(p<.01)$ in Part than in IVF counterparts (Figure 1), with two times more chance of Part zygotes to cleave $(\mathrm{OR}=2.02 ; \mathrm{Cl} 95 \%=1.4,2.8)$ than the IVF counterparts. In order to verify whether such difference on cleavage was determined by embryo stages, we also compared the development of presumptive zygotes towards different stages (2-cell, 4-cell and 8-cell) at 48 hpia. The heat shock during IVM had impact on development until 4-cell stages for IVF zygotes only; it decreased $(p<.05)$ the capacity of IVF zygotes to reach 4-cell stage (29.9 $\pm 4.7 \%)$ when compared to IVF control $(37.8 \pm 5.8 \%$; OR $=0.7 ; \mathrm{Cl} 95 \%=0.5,0.9)$ but also when compared to the Part control $(53.7 \pm 4.8 \%$; OR $=0.32 ; \mathrm{Cl} 95 \%=0.2$, 0.4 ) and Part heat shock (56.2 $\pm 4.1 \% ; \mathrm{OR}=0.28 ; \mathrm{Cl} 95 \%=0.2,0.3$ ) groups. However, no effect of heat shock was found $(p>.05)$ between Part groups. In contrast, heat shock decreased $(p<.05)$ the ability of zygotes to reach 8 -cell stage for both IVF $(7.9 \pm 2.9 \%$ vs. $4.2 \pm 1.3 \%$ for IVF control vs. heat shock, respectively; OR $=0.44 ; \mathrm{Cl}$ $95 \%=0.2,0.8)$ and Part (11.9 $\pm 3.7 \%$ vs. $7.5 \pm 1.5 \%$ for Part control vs. heat shock, respectively; $\mathrm{OR}=0.47 ; \mathrm{Cl} 95 \%=0.2,0.8$ ) groups. No difference was found for 2-cell stage between control and heat shock $(p>.05)$, but Part control had lower rate $(p<.01)$ than IVF control group $(12.3 \pm 1.7 \%$ vs. $21.1 \pm 3 \%$, respectively; $\mathrm{OR}=0.47, \mathrm{Cl}$ $95 \%=0.3,0.7)$.

Heat shock during IVM had a negative impact in the blastocyst formation in both IVF and Part embryos (Figure 1). Heat shock decreased $(p<.01)$ the capacity of IVF zygotes to reach blastocyst stage at $168 \mathrm{hpia}(\mathrm{OR}=0.51 ; \mathrm{Cl} 95 \%=0.3,0.7)$ and $192 \mathrm{hpia}(\mathrm{OR}=0.46$; $\mathrm{Cl} 95 \%=0.3,0.6)$ when compared to the IVF control group. Heat shock had similar effect on development after parthenogenesis, with lower chance $(p<.01)$ of Part zygotes from heat shock group to reach blastocyst stage at $168 \mathrm{hpia}(\mathrm{OR}=0.65 ; \mathrm{Cl} 95 \%=0.4,0.8)$ and 192 hpia $(O R=0.54 ; \mathrm{Cl} 95 \%=0.4,0.7)$ than those from the Part

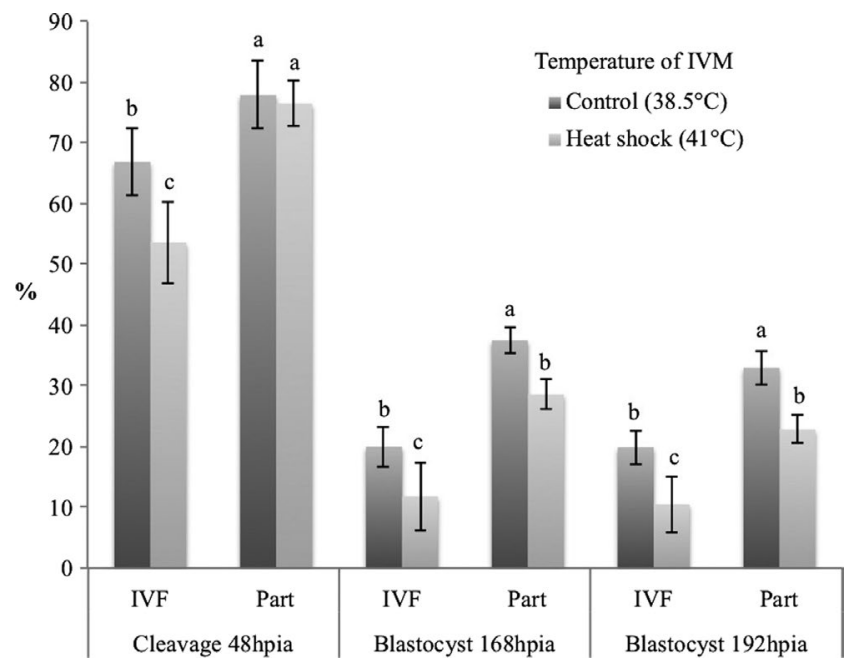

FIGURE 1 Cleavage and blastocyst rates at different hours post-insemination or chemical activation (hpia) for embryos derived from oocytes matured in vitro (IVM) under control $\left(38.5^{\circ} \mathrm{C} / 24 \mathrm{hr}\right.$ ) or heat shock $\left(41^{\circ} \mathrm{C} / 12 \mathrm{hr}\right.$ followed by $\left.38.5^{\circ} \mathrm{C} / 12 \mathrm{hr}\right)$ temperatures. Control in vitro fertilization (IVF): $n=456$ oocytes, heat shock IVF: $n=454$; control parthenogenesis (Part): $n=454$; heat shock Part: $n=488$; eleven replicates (three replicates were not evaluated at 48 hpia). Groups were compared by logistic regression (see odds ratio and confidence interval in Results section); letters above bars within the same variable indicate differences $(p<.01)$. Means are shown as mean \pm SEM 
control group. The blastocyst formation increased $(p<.01)$ in Part when compared to the IVF group (Figure 1). No significant interaction between temperature of IVM and method of oocyte activation was found for blastocyst development $(p>.05)$.

\subsection{Effect of temperature during IVM and of method of oocyte activation on blastocyst total cell number and apoptosis}

Total cell number and total apoptotic cell number were assessed by TUNEL assay. In the IVF and Part groups, the heat shock during IVM did not affect $(p>.05)$ the total cell number and total apoptotic cell number in blastocysts when compared to respective control and there was no significant interaction between temperature of IVM and method of activation. Nevertheless, parthenogenetic blastocysts had lower total cell number $(p<.05)$ than IVF counterparts (Figure 2). Heat shock during IVM did not influence $(p>.05)$ the proportion of apoptotic cells in IVF blastocysts. In contrast, parthenogenetic blastocysts from heat-shocked oocytes had greater $(p<.05)$ index of apoptotic cells $(\mathrm{OR}=1.16 ; \mathrm{Cl} 95 \%=1.01,1.33)$ than the control. Parthenogenesis also increased $(p<.01)$ the index of apoptotic cells $(\mathrm{OR}=1.56 ; \mathrm{Cl} 95 \%=1.3,1.8)$ when compared to in vitro fertilization (Figure 2).

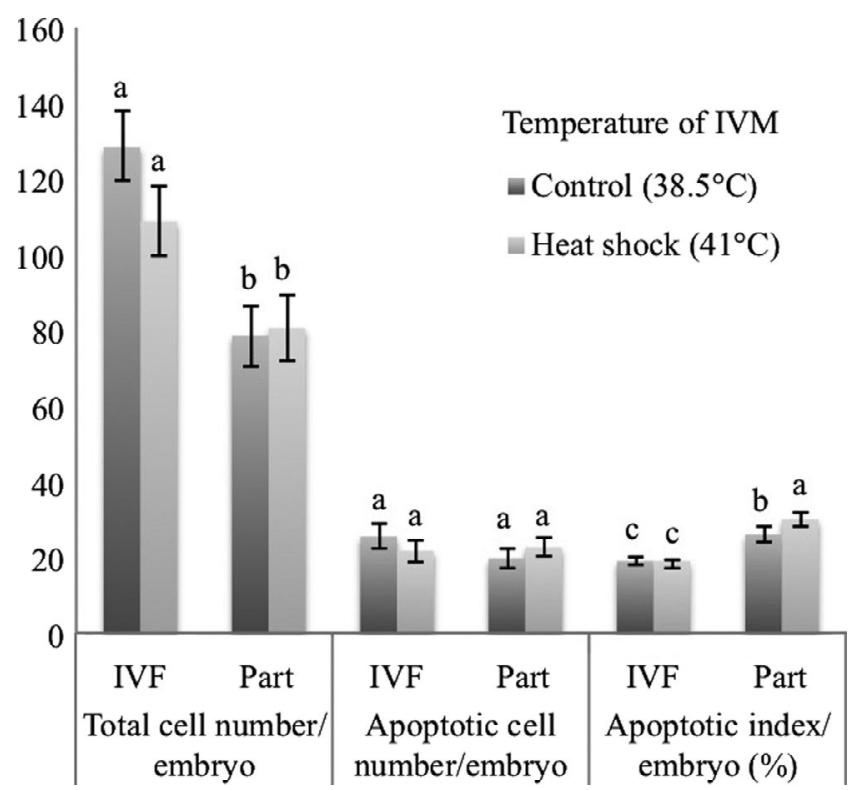

FIGURE 2 Total cell number and apoptosis for embryos at blastocysts stage at $192 \mathrm{hr}$ post-insemination or activation (hpia) derived from oocytes matured in vitro (IVM) under control $\left(38.5^{\circ} \mathrm{C} / 12 \mathrm{hr}\right)$ or heat shock $\left(41^{\circ} \mathrm{C} / 12 \mathrm{hr}\right.$ followed by $\left.38.5^{\circ} \mathrm{C} / 12 \mathrm{hr}\right)$ temperatures. Control in vitro fertilization (IVF): $n=27$ blastocysts, heat shock IVF: $n=18$; control parthenogenesis (Part): $n=27$; heat shock parthenogenesis: $n=25$. Groups were compared by linear mixed model (for variables, total cell number and number of apoptotic cells) or by logistic regression (for apoptotic index; see odds ratio and confidence interval in Results section); letters above bars within the same variable show differences $(p<.01)$. Means are shown as mean \pm SEM

\subsection{Effect of temperature during IVM on gene expression in IVF or Part blastocysts}

Relative expression of specific genes in IVF or Part blastocysts derived from heat-shocked oocytes was assessed by real-time PCR (Figure 3). The expression of HSP70.1 was up-regulated $(p<.01)$, whereas the expression of AQP3 was down-regulated $(p<.01)$ in Part blastocysts derived from heat-shocked oocytes when compared to the control group. Expression of ATP1A1 was down-regulated $(p<.05)$ in IVF blastocyst derived from heat-shocked oocytes, and no significant effect of heat shock during IVM was found on expression of PRDX1.

\section{DISCUSSION}

The effect of high temperatures on oocyte developmental competence in bovine is well documented. Heat shock during in vitro maturation reduces the ability of the oocyte to progress to blastocyst stage after in vitro fertilization (Edwards \& Hansen, 1997; Roth \& Hansen, 2004a). In the present study, we found that the temperature during IVM affects the development not only of in vitro-fertilized but also of parthenogenetic embryos. However, developmental disparities were found at $48 \mathrm{hpia}$. Cleavage rates were lower in IVF embryos from heat-shocked oocytes than in the control and Part embryos, but no difference was found between Part embryos obtained from control and heat-shocked oocytes. In contrast, Part blastocysts derived from heat-shocked oocytes had greater apoptotic index and expression of HSP70.1 gene when compared to those derived from control; however, such differences were not found between IVF embryos derived from heat-shocked and control oocytes.

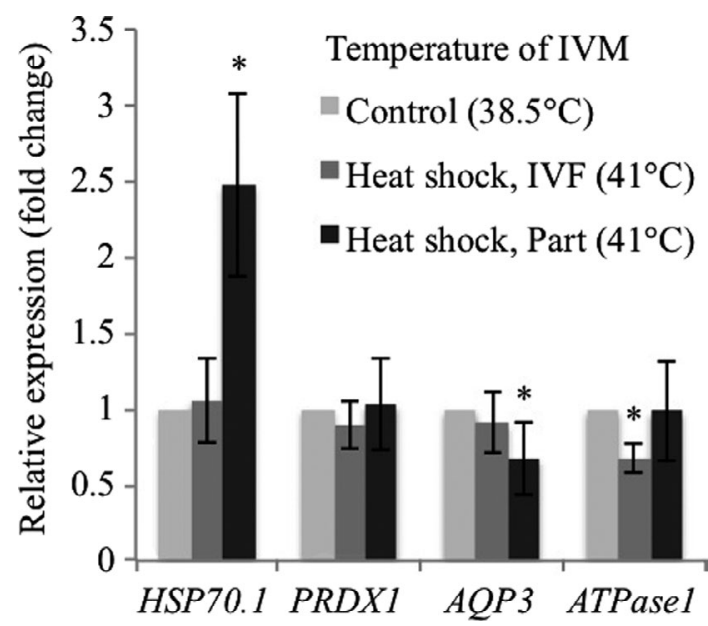

FIGURE 3 Relative amount of specific transcripts for in vitrofertilized (IVF) or parthenogenetic (Part) blastocysts derived from oocytes matured in vitro (IVM) under $41^{\circ} \mathrm{C} / 12 \mathrm{hr}$ followed by $38.5^{\circ} \mathrm{C} / 12 \mathrm{hr}$ (heat shock). Bars with asterisk $\left({ }^{*}\right)$ within gene differ $(p<.05)$ from the control group (IVM under $38.5^{\circ} \mathrm{C} / 24 \mathrm{hr}$ ). Data of control group were used as calibrator (set to 1 ), and means are shown as fold change (mean $\pm S E M$ ) relative to the calibrator 
Similarly to our cleavage data, previous study did not find effect of heat shock during IVM on cleavage at 69-74 hr post-activation with ionomycin (Rispoli et al., 2011). However, that same study reported no effect of heat shock on cleavage for IVF embryos, which contrast to our finding. The detrimental effect of heat shock during IVM on cleavage rate of IVF embryos is contradictory, being supported by some studies (Kalo \& Roth, 2011; Roth \& Hansen, 2004a, 2004b), but not by others (Edwards et al., 2009; Edwards, Saxton, Lawrence, Payton, \& Dunlap, 2005; Ju, Jiang, Tseng, Parks, \& Yang, 2005). Nevertheless, it was reported that a lower percentage of oocytes developed towards 4 -cell stage at $44 \mathrm{hr}$ post-insemination when IVM was performed under heat shock conditions, suggesting that the high temperature during oocyte maturation can impair the second embryonic division (Meiyu, Liu, \& Roth, 2015). Other study reported lower proportion of embryos with 3-4 cells at 70-72 hr post-fertilization when in vitro maturation was performed under $40^{\circ} \mathrm{C}$ (Diez et al., 2009). We found lower cleavage rate at $48 \mathrm{hpia}$ in the heat-shocked oocytes, which was mainly due to the low percentage of 4-cell stage embryos, supporting the concept that heat shock during oocyte maturation can impair the early embryonic division after fertilization. However, such result differs from that following parthenogenesis, where no alteration on cleavage rate at 4-cell stage was found.

The reasons for contrasting effects on early cleavages after fertilization and parthenogenesis of heat-shocked oocytes may be related to fertilization per se, but biological differences between IVF and Part embryos can also be involved. Lower cleavage rate after IVF may be due to the low ability of heat-shocked oocytes to be fertilized. Indeed, we found lower pronucleus formation in presumptive zygotes from heat-shocked oocytes, which is in agreement with other study that reported a higher rate of unfertilized heat-stressed oocytes (Roth \& Hansen, 2005). The low fertilization can be one of the reasons for lower cleavage at $48 \mathrm{hr}$ post-fertilization, but it does not contribute much to explain the lower percentage of 4-cell stage IVF embryos derived from heat-shocked oocytes. Differences between in vitro fertilization and parthenogenesis may also play a role in such contrasting effect on early development of embryos from heat-shocked oocytes. For instance, IVF zygotes display an increased level of reactive oxygen species (ROS), whereas Part zygotes display a decreased level (Morado, Cetica, Beconi, Thompson, \& Dalvit, 2013). As heat shock can increase the ROS production in oocytes (Ascari et al., 2017), the levels of ROS can reach deleterious levels following the fertilization of a heat-shocked oocyte impairing the early cleavages, but not after parthenogenesis. Other difference between IVF and parthenogenetic embryos is the calcium releasing at oocyte activation. While the chemical activation with ionomycin induces a single and large calcium release (Alberio, Zakhartchenko, Motlik, \& Wolf, 2001; Jellerette et al., 2006), the fertilization sperm factors trigger a series of calcium oscillations (Alberio et al., 2001; Miyazaki \& Ito, 2006), which effect is mediated by the oocyte machinery (Alberio et al., 2001; Tang et al., 2000). Also, nuclei of fertilized one- and two-cell embryos have calcium-releasing activity provided by the sperm, in contrast to parthenogenetic embryos
(Kono, Carroll, Swann, \& Whittingham, 1995). In this context, heat shock could disturb the oocyte machinery and decrease the ability of oocyte to be activated by sperm factors or even disturb the calcium releasing required for the first embryonic divisions.

One aspect to consider is a male effect when analysing data of in vitro fertilization. Differences among bulls on cleavage and blastocyst production have been reported (Camargo, Sa, Ferreira, Viana, \& Araujo, 2002) and might also influence the cleavage of heat-shocked oocytes. In contrast, chemical activation generally results in steady cleavage rates. Some evidences support the role of paternal epigenome and other sperm factors, such as mRNAs and microRNAs precursors, on embryogenesis (Dadoune, 2009; Grandjean \& Rassoulzadegan, 2009; Hamatani, 2012; Jenkins \& Carrell, 2012; Yuan et al., 2016), but it is not well known whether they can vary according to the male and influence early cleavage. The sperm microRNA-34c is an example of potential sperm factor; it is transmitted to the mouse oocyte during fertilization, but it is absent in ethanol-activated oocytes. Most of in vitro-fertilized zygotes injected with microRNA34-c inhibitor fails to cleave, suggesting its role on first cell division; however, parthenogenetic zygotes can cleave in the absence of microRNA-34c (Liu et al., 2012), which indicates differences between fertilized and parthenogenetic zygotes. In humans, it was found that level of sperm microRNA-34c among patients with different fertilities is correlated with embryo quality and pregnancy but not with fertilization or cleavage (Cui, Fang, Shi, Qiu, \& Ye, 2015). Those sorts of sperm factors may be affected by oocyte components. Pre-microRNAs are cleaved into mature microRNAs by Dicer ribonuclease (Luense, Carletti, \& Christenson, 2009), and the lack of Dicer function impairs oocyte maturation (Liu, Tang, He, \& Rosenwaks, 2010) and leads to infertility in mouse (Bernstein et al., 2003). It was shown that the expression of Dicer protein is elevated in somatic cells exposed to mild heat stress (Oshlag, Devasthanam, \& Tomasi, 2013). Modulation of Dicer protein in the oocyte by heat shock could suggest an altered processing of potential sperm microRNAs required for the first cleavages; however, there are no data showing the status of Dicer in heat-shocked oocytes.

Despite the early cleavage disparity between IVF and Part embryos, the heat shock during IVM reduced the blastocyst production in both IVF and Part groups. The negative impact of heat shock during IVM on blastocyst production after in vitro fertilization is in agreement with other reports (Edwards \& Hansen, 1997; Roth \& Hansen, 2004a). In vitro-fertilized blastocysts derived from heat-shocked oocytes did not exhibit alterations on total cell number, proportion of apoptotic cells and expression of HSP70.1 gene, in spite of the lower blastocyst rate when compared to the respective control. Indeed, early study reported that blastocyst derived from heat-shocked oocyte may display no alteration on apoptotic index (Roth \& Hansen, 2004a). As an elevated expression of HSP70.1 can be considered a response to cellular stress and injuries (Silver \& Noble, 2012), the absence of alteration on expression of that gene might indicate that the IVF blastocysts from heat-shocked oocytes were no longer under the effect of heat shock. However, the low 
expression of ATP1A1 gene, which encodes a protein important for active ion transport across the trophectoderm and fluid movement to the blastocoel (Watson, Westhusin, Sousa, Betts, \& Barcroft, 1999), could affect the ability of IVF blastocyst to expand the blastocoel, compromising the embryo hatching. Thus, an effect of heat stress during IVM may still persist as an epigenetic modification. In contrast to IVF blastocyst, Part blastocysts had lower total cell number and higher apoptotic index demonstrating the effect of chemical activation and absence of paternal genome on embryo quality. Interestingly, the heat shock increased the apoptotic index and expression of HSP70.1 and decreased the expression of AQP3 in those Part blastocysts only. AQP3 encodes a protein that plays role on embryo cavitation allowing water movement across the trophectoderm (Barcroft, Offenberg, Thomsen, \& Watson, 2003) and disturbs on its expression may impair osmosis regulation in Part blastocyst. Those findings suggest that heat shock during IVM can have a greater impact on quality of Part blastocysts than in IVF counterparts.

Overall, this study shows the influence of method of activation on early development of embryos derived from heat-shocked oocytes, which is represented by lower ability to cleave after in vitro fertilization than after parthenogenesis. Such divergent effect may be a consequence of low fertilization rate or a more efficient chemical activation, which may attenuate the effect of heat shock during IVM on early development. Other possibility is a low ability of heatshocked oocytes to process sperm factors required for activation and early cleavage. Nonetheless, better quality blastocyst can be found after in vitro fertilization than after parthenogenesis of heatshocked oocytes, although it is still unclear whether IVF blastocysts from heat-shocked oocytes are able to keep their full competence since expression of some genes in those embryos might be influenced by the heat shock before fertilization. Our data highlight the need to study the factors involved in the activation of heat-shocked oocytes and whether they can be modulated in order to enhance early embryo development in regions where heat stress is an issue for in vitro embryo production systems.

\section{ACKNOWLEDGMENTS}

This study was supported by the National Council for Scientific and Technological Development (CNPq) and Fapemig (APQ 543-14 and CVZ-PPM 107-17).

\section{CONFLICT OF INTEREST}

None of the authors have any conflict of interest to declare.

\section{AUTHOR CONTRIBUTIONS}

We declare that all authors have made substantial contributions to the research and manuscript as follows: Camargo, Munk and Costa contributed to the conception and design of the experiments, data interpretation and analysis; Wohlres-Viana, Vieira, Serapiao and Campos Jr contributed to oocyte processing and in vitro embryo production, apoptosis analysis and data interpretation; Carvalho, Nogueira and Viana contributed to drafting the article and revision. All authors contributed to the final revision of the manuscript. All authors are aware of the submission and agree to be listed as co-authors. They declare that there is no conflict of interest.

\section{DATA AVAILABILITY}

The data that support the findings of this study are available from the corresponding author upon reasonable request. Dataset Camargo 2019_RDA. Data available at the following link upon reasonable request: https://drive.google.com/drive/folders/1GVBDOHDIxV-RZzP_GwJ3v9UI3yyrjPi?usp=sharing.

\section{ORCID}

Luiz Sergio Almeida Camargo (iD https://orcid. org/0000-0001-9974-711X

\section{REFERENCES}

Alberio, R., Zakhartchenko, V., Motlik, J., \& Wolf, E. (2001). Mammalian oocyte activation: Lessons from the sperm and implications for nuclear transfer. International Journal of Development Biology, 45, 797-809.

Amdani, S. N., Yeste, M., Jones, C., \& Coward, K. (2015). Sperm factors and oocyte activation: Current controversies and considerations. Biology of Reproduction, 93, 1-8. https://doi.org/10.1095/biolr eprod.115.130609

Ascari, I. J., Alves, N. G., Jasmin, J., Lima, R. R., Quintao, C. C. R., Oberlender, G., ... Camargo, L. S. A. (2017). Addition of insulin-like growth factor I to the maturation medium of bovine oocytes subjected to heat shock: Effects on the production of reactive oxygen species, mitochondrial activity and oocyte competence. Domestic Animal Endocrinology, 60, 50-60. https://doi.org/10.1016/j.doman iend.2017.03.003

Barcroft, L. C., Offenberg, H., Thomsen, P., \& Watson, A. J. (2003). Aquaporin proteins in murine trophectoderm mediate transepithelial water movements during cavitation. Developmental Biology, 256, 342-354. https://doi.org/10.1016/S0012-1606(02)00127-6

Bernstein, E., Kim, S. Y., Carmell, M. A., Murchison, E. P., Alcorn, H., Li, M. Z., ... Hannon, G. J. (2003). Dicer is essential for mouse development. Nature Genetics, 35, 215-217. https://doi.org/10.1038/ng1253

Boerke, A., Dieleman, S. J., \& Gadella, B. M. (2007). A possible role for sperm RNA in early embryo development. Theriogenology, 68(Suppl 1), S147-S155. https://doi.org/10.1016/j.theriogenology.2007.05.058

Bui, H. T., Wakayama, S., Mizutani, E., Park, K. K., Kim, J. H., Van, T. N., \& Wakayama, T. (2011). Essential role of paternal chromatin in the regulation of transcriptional activity during mouse preimplantation development. Reproduction, 141, 67-77. https://doi.org/10.1530/ REP-10-0109

Camargo, L. S. A., Sa, W. F., Ferreira, A. M., Viana, J. H. M., \& Araujo, M. C. C. (2002). Effect of sperm concentration and incubation period of oocyte spermatozoa on in vitro fertilization in the Gir breed. Pesquisa Agropecuaria Brasileira, 37, 709-715. https://doi.org/10.1590/S0100204X2002000500017

Cui, L., Fang, L., Shi, B., Qiu, S., \& Ye, Y. (2015). Spermatozoa micro ribonucleic acid-34c level is correlated with intracytoplasmic sperm injection outcomes. Fertility and Sterility, 104, 312-317.e1. https:// doi.org/10.1016/j.fertnstert.2015.05.003 
Dadoune, J. P. (2009). Spermatozoal RNAs: What about their functions? Microscopy Research Technique, 72, 536-551. https://doi. org/10.1002/jemt.20697

Diez, C., Bermejo-Alvarez, P., Trigal, B., Caamaño, J. N., Muñoz, M., Molina, I., ... Gomez, E. (2009). Changes in testosterone or temperature during the in vitro oocyte culture do not alter the sex ratio of bovine embryos. Journal of Experimental Zoology Part A Ecological Genetics and Physiology, 311, 448-452. https://doi.org/10.1002/ jez.540

Ealy, A. D., Drost, M., \& Hansen, P. J. (1993). Developmental changes in embryonic resistance to adverse effects of maternal heat stress in cows. Journal of Dairy Science, 76, 2899-2905. https://doi. org/10.3168/jds.S0022-0302(93)77629-8

Edwards, J. L., Bogart, A. N., Rispoli, L. A., Saxton, A. M., \& Schrick, F. N. (2009). Developmental competence of bovine embryos from heat-stressed ova. Journal of Dairy Science, 92, 563-570. https://doi. org $/ 10.3168 /$ jds.2008-1495

Edwards, J. L., \& Hansen, P. J. (1997). Differential responses of bovine oocytes and preimplantation embryos to heat shock. Molecular Reproduction and Development, 46, 138-145.

Edwards, J. L., Saxton, A. M., Lawrence, J. L., Payton, R. R., \& Dunlap, J. R. (2005). Exposure to a physiologically relevant elevated temperature hastens in vitro maturation in bovine oocytes. Journal of Dairy Science, 88, 4326-4333. https://doi.org/10.3168/jds. S0022-0302(05)73119-2

Gendelman, M., Aroyo, A., Yavin, S., \& Roth, Z. (2010). Seasonal effects on gene expression, cleavage timing, and developmental competence of bovine preimplantation embryos. Reproduction, 140, 73-82. https://doi.org/10.1530/REP-10-0055

Gendelman, M., \& Roth, Z. (2012a). Seasonal effect on germinal vesiclestage bovine oocytes is further expressed by alterations in transcript levels in the developing embryos associated with reduced developmental competence. Biology of Reproduction, 86, 1-9. https://doi. org/10.1095/biolreprod.111.092882

Gendelman, M., \& Roth, Z. (2012b). In vivo vs. in vitro models for studying the effects of elevated temperature on the GV-stage oocyte, subsequent developmental competence and gene expression. Animal Reproduction Science, 134, 125-134. https://doi.org/10.1016/j.anire prosci.2012.07.009

Grandjean, V., \& Rassoulzadegan, M. (2009). Epigenetic inheritance of the sperm: An unexpected role of RNA. Gynecologie Obstetrique and Fertilite, 37, 558-561. https://doi.org/10.1016/j.gyobfe.2009.04.005

Hamatani, T. (2012). Human spermatozoal RNAs. Fertility and Sterility, 97, 275-281. https://doi.org/10.1016/j.fertnstert.2011.12.035

Hansen, P. J., Drost, M., Rivera, R. M., Paula-Lopes, F. F., Al-Katanani, Y. M., Krininger, C. E., \& Chase, C. C. (2001). Adverse impact of heat stress on embryo production: Causes and strategies for mitigation. Theriogenology, 55, 91-103. https://doi.org/10.1016/ S0093-691X(00)00448-9

Jellerette, T., Melican, D., Butler, R., Nims, S., Ziomek, C., Fissore, R., \& Gavin, W. (2006). Characterization of calcium oscillation patterns in caprine oocytes induced by IVF or an activation technique used in nuclear transfer. Theriogenology, 65, 1575-1586. https://doi. org/10.1016/j.theriogenology.2005.08.025

Jenkins, T. G., \& Carrell, D. T. (2012). The sperm epigenome and potential implications for the developing embryo. Reproduction, 143, 727-734. https://doi.org/10.1530/REP-11-0450

Ju, J. C., Jiang, S., Tseng, J. K., Parks, J. E., \& Yang, X. (2005). Heat shock reduces developmental competence and alters spindle configuration of bovine oocytes. Theriogenology, 64, 1677-1689. https://doi. org/10.1016/j.theriogenology.2005.03.025

Kalo, D., \& Roth, Z. (2011). Involvement of the sphingolipid ceramide in heat-shock-induced apoptosis of bovine oocytes. Reproduction, Fertility and Development, 23, 876-888. https://doi.org/10.1071/ RD10330
Kono, T., Carroll, J., Swann, K., \& Whittingham, D. G. (1995). Nuclei from fertilized mouse embryos have calcium-releasing activity. Development, 121, 1123-1128.

Liu, H. C., Tang, Y., He, Z., \& Rosenwaks, Z. (2010). Dicer is a key player in oocyte maturation. Journal of Assisted Reproduction and Genetics, 27, 571-580. https://doi.org/10.1007/s10815-010-9456-x

Liu, W. M., Pang, R. T., Chiu, P. C., Wong, B. P., Lao, K., Lee, K. F., \& Yeung, W. S. (2012). Sperm-borne microRNA-34c is required for the first cleavage division in mouse. Proceedings of National Academy of Science of United States of America, 109, 490-494. https://doi. org/10.1073/pnas.1110368109

Luense, L. J., Carletti, M. Z., \& Christenson, L. K. (2009). Role of Dicer in female fertility. Trends in Endocrinology and Metabolism, 20, 265-272. https://doi.org/10.1016/j.tem.2009.05.001

Meiyu, Q., Liu, D., \& Roth, Z. (2015). IGF-I slightly improves nuclear maturation and cleavage rate of bovine oocytes exposed to acute heat shock in vitro. Zygote, 23, 514-524. https://doi.org/10.1017/S0967 19941400015X

Miyazaki, S., \& Ito, M. (2006). Calcium signals for egg activation in mammals. Journal of Pharmacological Sciences, 100, 545-552. https://doi. org/10.1254/jphs.CPJ06003X

Morado, S., Cetica, P., Beconi, M., Thompson, J. G., \& Dalvit, G. (2013). Reactive oxygen species production and redox state in parthenogenetic and sperm-mediated bovine oocyte activation. Reproduction, 145, 471-478. https://doi.org/10.1530/REP-13-0017

Oshlag, J. Z., Devasthanam, A. S., \& Tomasi, T. B. (2013). Mild hyperthermia enhances the expression and induces oscillations in the Dicer protein. International Journal of Hyperthermia, 29, 51-61. https://doi. org/10.3109/02656736.2012.753471

Pfaffl, M. W., Horgan, G. W., \& Dempfle, L. (2002). Relative expression software tool (REST) for group-wise comparison and statistical analysis of relative expression results in real-time PCR. Nucleic Acids Research, 30, e36. https://doi.org/10.1093/nar/30.9.e36

Putney, D. J., Drost, M., \& Thatcher, W. W. (1988). Embryonic development in superovulated dairy cattle exposed to elevated ambient temperatures between Days 1 to 7 post insemination. Theriogenology, 30, 195-209. https://doi.org/10.1016/0093-691X(88)90169-0

Ramakers, C., Ruijter, J. M., Deprez, R. H., \& Moorman, A. F. (2003). Assumption-free analysis of quantitative real-time polymerase chain reaction (PCR) data. Neuroscience Letters, 339, 62-66. https://doi. org/10.1016/S0304-3940(02)01423-4

Rispoli, L. A., Lawrence, J. L., Payton, R. R., Saxton, A. M., Schrock, G. E., Schrick, F. N., ... Edwards, J. L. (2011). Disparate consequences of heat stress exposure during meiotic maturation: Embryo development after chemical activation vs fertilization of bovine oocytes. Reproduction, 142, 831-843. https://doi.org/10.1530/REP-11-0032

Ross, P. J., Beyhan, Z., lager, A. E., Yoon, S. Y., Malcuit, C., Schellander, K., ... Cibelli, J. B. (2008). Parthenogenetic activation of bovine oocytes using bovine and murine phospholipase $C$ zeta. BMC Developmental Biology, 8, 16. https://doi.org/10.1186/1471-213X-8-16

Roth, Z., \& Hansen, P. J. (2004a). Involvement of apoptosis in disruption of developmental competence of bovine oocytes by heat shock during maturation. Biology of Reproduction, 71, 1898-1906. https:// doi.org/10.1095/biolreprod.104.031690

Roth, Z., \& Hansen, P. J. (2004b). Sphingosine 1-phosphate protects bovine oocytes from heat shock during maturation. Biology of Reproduction, 71, 2072-2078. https://doi.org/10.1095/biolr eprod.104.031989

Roth, Z., \& Hansen, P. J. (2005). Disruption of nuclear maturation and rearrangement of cytoskeletal elements in bovine oocytes exposed to heat shock during maturation. Reproduction, 129, 235-244. https://doi.org/10.1530/rep.1.00394

Silver, J. T., \& Noble, E. G. (2012). Regulation of survival gene hsp70. Cell Stress and Chaperones, 17, 1-9. https://doi.org/10.1007/ s12192-011-0290-6 
Tang, T. S., Dong, J. B., Huang, X. Y., \& Sun, F. Z. (2000). Ca(2+) oscillations induced by a cytosolic sperm protein factor are mediated by a maternal machinery that functions only once in mammalian eggs. Development, 127, 1141-1150.

Watson, A. J., Westhusin, M. E., De Sousa, P. A., Betts, D. H., \& Barcroft, L. C. (1999). Gene expression regulating blastocyst formation. Theriogenology, 51, 117-133. https://doi.org/10.1016/ S0093-691X(98)00236-2

Yeste, M., Jones, C., Amdani, S. N., \& Coward, K. (2017). Oocyte activation and fertilisation: Crucial contributors from the sperm and oocyte. Results and Problems in Cell Differentiation, 59, 213-239. https:// doi.org/10.1007/978-3-319-44820-6_8

Yuan, S., Schuster, A., Tang, C., Yu, T., Ortogero, N., Bao, J., ... Yan, W. (2016). Sperm-borne miRNAs and endo-siRNAs are important for fertilization and preimplantation embryonic development. Development, 143, 635-647. https://doi.org/10.1242/dev.131755

How to cite this article: Camargo LSA, Costa FQ, Munk M, et al. Contrasting effects of heat shock during in vitro maturation on development of in vitro-fertilized and parthenogenetic bovine embryos. Reprod Dom Anim. 2019;54:1357-1365. https://doi.org/10.1111/rda.13544 